\title{
Pembuatan Penghitung Jumlah Mobil Otomatis Berbasis Mikrokontroler ATMega 8535 Menggunakan Sensor Ultrasonik
}

\author{
Riko Dede Hardiyanto, Adian Fatchur Rochim, Ike Pertiwi Windasari \\ Program Studi Sistem Komputer Fakultas Teknik Universitas Diponegoro \\ Jalan Prof. Sudharto, Tembalang, Semarang, Indonesia \\ rikodede@ce.undip.ac.id
}

\begin{abstract}
Car drivers often experience difficulties to park their cars in the parking lot there is a slot or an empty space with a limited number. For example, some parking places such as shopping centers, apartments and hotels. To determine the state of the parking spaces have been filled or not it is necessary to update the conditions in the room. The purpose of this thesis is to create a functioning device calculates and displays the number of entrances. A number of automatically calculating devices have been made. General description of the device is designed to use the SRF04 ultrasonic sensor, microcontroller ATMega8535, and buzzer. SRF04 ultrasonic sensors as detecting obstructions between the ends of the door with the barrier wall and counting. With the existence of this device in the state of the room can be determined easily and saves time.
\end{abstract}

Key Terms : SRF04 ultrasonic sensor, microcontroller ATmega 8535, buzzer

\section{PENDAhUluan}

$\mathrm{K}$ EBUTUHAN akan efektifitas, efisiensi serta manajemen waktu sangat diutamakan dalam berbagi bidang. Mendorong manusia untuk selalu berkreasi dan berinovasi dalam berbagai bidang khususnya ilmu dan teknologi menciptakan sesuatu yang lebih efisien dan praktis. Untuk mendukung itu semua dibuatlah alat penghitung mobil otomatis ini. Menggunakan studi kasus pada area parkir, kejadian yang sering terjadi suatu ketika ingin memarkir kendaraan ditempat parkir dan ternyata tempat parkir tersebut telah terisi penuh oleh kendaraan, apabila dipaksakan memarkir tentunya membuat permasalahan bagi pihak penyedia lahan parkir tersebut. Sebagai pemilik kendaraan juga tidak mau dirugikan dengan keadaan parkir penuh tersebut, sehingga menyebabkan konflik antara penyedia parkir dan pengemudi. Maka dengan memanfaatkan teknologi yang dapat dikembangkan ini diharapkan dapat membantu dan mengatasi permasalahan tempat parkir penuh.

Penelitian ini bertujuan membuat perangkat yang menampilkan informasi kepada pengemudi kendaraan sehingga pengemudi yang akan memarkir kendaraan dengan mengetahui jumlah maksimal kendaraan yang ada di ruang parkir. Dengan menggunakan sensor Ultrasonik SRF04 sebagai sensor dan mikrokontroler ATMega 8535 sebagai pemroses, LCD sebagai penampil informasi, dan buzzer sebagai penghantar bunyi.

\section{TINJAUAN PUSTAKA}

\section{A. Mikrokontroler}

Mikrokontroler adalah suatu chip (rangkaian terintegrasi-IC) VLSI (Very Large Scale IC) mikroprosesor yang dikhususkan untuk instrumentsasi dan kendali yang bersifat reprogramable (dapat diprogram berulang kali sesuai kebutuhan). Mikrokontroler memiliki unit memori sendiri (meskipun sangat terbatas), unit I/O yang dapat dikoneksikan langsung dengan sensor atau akuator. Memori disimpan dalam memori yang tidak dapat hilang bila catu daya padam, biasanya dalam bentuk ROM, PROM (Programmable Read Only Memory) atau EPROM (Erasable Programmble Read Only Memory) diluar mikrokontroler, atau beberapa seri atau varian memiliki ROM didalam mikrokontroler itu sendiri.( Sudjadi, 2005).

\section{B. Mikrokontroler ATMega 8535}

Mikrokontroler AVR berteknologi RISC (Reduced Instruction Set Computing). Secara umum, AVR dikelompokkan menjadi 4 kelas, yaitu keluarga ATtiny, keluarga AT90Sxx, keluarga ATMega dan keluarga AT86RFxx. Pada dasarnya yang membedakan masing-masing kelas adalah memori, peripheral, dan fiturnya (Wardhana, 2006).

Mikrokontroler ATMega8535 memiliki sebanyak 40 pin dapat dilihat pada gambar 1. Dari gambar tersebut dapat dijelaskan secara fungsional konfigurasi pin ATMega8535 sebagai berikut:

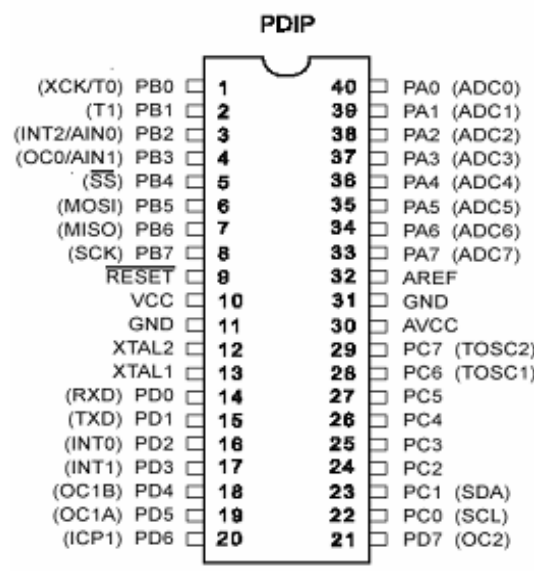

Gambar 1. Konfigurasi pin ATMega8535 


\section{Sensor}

sensor adalah alat untuk mendeteksi / mengukur sesuatu yang digunakan untuk mengubah variasi mekanis, magnetis, panas, sinar dan kimia menjadi tegangan dan arus listrik. Dalam lingkungan sistem pengendali dan robotika, sensor memberikan kesamaan yang menyerupai mata, pendengaran, hidung, lidah manusia yang kemudian akan diolah oleh kontroller sebagai otaknya.

\section{Gelombang Ultrasonik}

Gelombang ultrasonik dapat didefinisikan sebagai gelombang suara atau gelombang akustik yang memiliki frekuensi mulai $20 \mathrm{kHz}$ hingga $20 \mathrm{MHz}$. Secara alami hewan kelelawar menghasilkan menghasilkan gelombang ultrasonik untuk mengenali lingkungannya.

\section{E. Sensor Ultrasonik}

Sensor ultrasonik merupakan sebuah sensor yang mengubah dari besaran fisis (bunyi) menjadi besaran listrik. Pada sensor gelombang ultrasonik dibangkitkan melalui sebuah benda yang disebut piezoelektric. Piezoelektric yang akan menghasilkan gelombang ultrasonik dengan frekuensi $40 \mathrm{kHz}$ ketika sebuah osilator diterapkan pada benda tersebut.

Prinsip kerja sensor ini adalah sebagai transmitter mengirimkan seberkas gelombang ultrasonik, lalu diukur waktu yang dibutuhkan hingga datangnya pantulan dari obyek. Prinsip kerja dari sensor ultrasonik ditunjukan pada gambar 2.berikut.

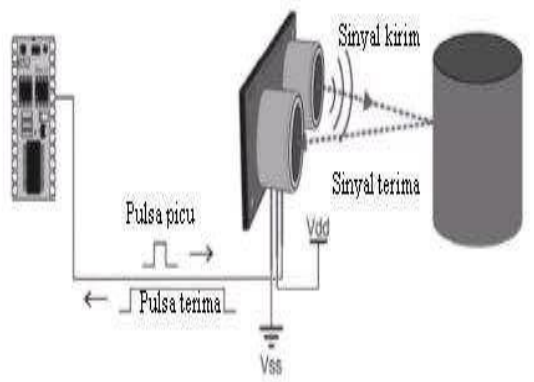

Gambar 2. Prinsip kerja pemantulan gelombang ultrasonik

Rangkaian penyusun sensor ultrasonik terdiri dari transmitter, reiceiver, dan komparator. Selain itu, gelombang ultrasonik dibangkitkan oleh sebuah kristal tipis bersifat piezoelektrik.

a. Perangkat piezoelektric secara langsung mengubah energi listrik menjadi energi mekanik. Tegangan input yang digunakan menyebabkan bagian keramik meregang dan memancarkan gelombang ultrasonik.

b. Transmitter merupakan alat yang berfungsi sebagai pemancar gelombang ultrasonik dengan frekuensi sebesar 40 $\mathrm{kHz}$ yang dibangkitkan dari sebuah osilator.

c. Receiver terdiri dari transduser ultrasonik menggunakan bahan piezoelektric, berfungsi sebagai penerima gelombang pantulan yang berasal dari transmitter yang dikenakan pada permukaan suatu benda atau gelombang langsung LOS (Line of Sight) dari transmitter.

\section{F. Sensor Jarak Ultrasonik SRF04}

Merupakan sensor non-kontak pengukur jarak yang menggunakan gelombang ultrasonik. Sensor ultrasonik dapat berfungsi sebagai pemancar maupun penerima gelombang ultrasonik. Seperti pada gambar 3. yang menunjukan bentuk fisik dari sensor yltrasonik SRF04.

Jurnal Teknologi dan Sistem Komputer, Vol.3, No.2, April 2015 (e-ISSN: 2338-0403)

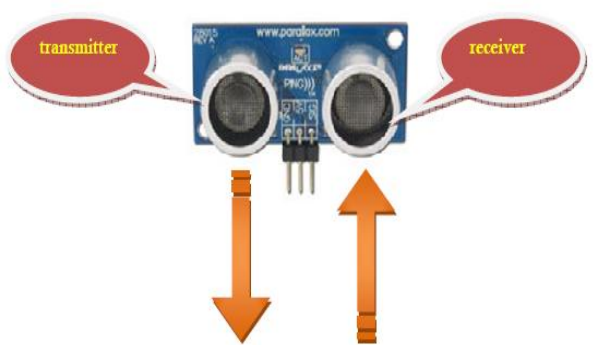

Gambar 3. Bentuk fisik sensor SRF04

\section{G.Liquid Crystal Display (LCD)}

LCD sebagai salah satu komponen yang dapat menampilkan perintah-perintah yang akan dijalankan oleh pemakai. LCD sendiri mempunyai kemampuan untuk menampilkan tidak hanya angka, bahkan huruf abjad, dan kata-kata tapi juga simbol-simbol.

Jenis serta ukuran LCD bermacam-macam, antara lain 2x16, 2x20, 2x40, dan lain-lain. LCD mempunyai dua bagian penting yaitu backlight yang berguna jika digunakan pada malam hari dan contrast yang berfungsi untuk mempertajam tampilan.

Berikut bentuk fisik dari LCD 16x2 ditunjukan pada gambar 4.

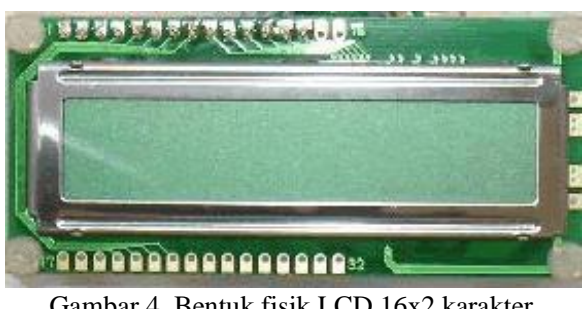

H.Buzzer

Buzzer adalah sebuah komponen elektronika yang berfungsi untuk mengubah getaran listrik menjadi getaran suara. buzzer terdiri dari kumparan yang terpasang pada diafragma saat kumparan tersebut dialiri arus akan menimbulkan gaya elektro magnet dan kumparan akan tertarik ke dalam atau keluar, karena kumparan dipasang pada diafragma maka setiap gerakan kumparan akan menggerakkan diafragma secara bolak-balik sehingga membuat udara bergetar yang akan menghasilkan suara seperti terlihat pada gambar 5 .

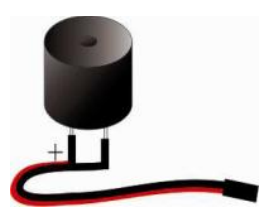

Gambar 5. Bentuk fisik Buzzer

\section{Bahasa Pemrograman Mikrokontroller}

Mikrokontroler memiliki tipe bahasa pemrograman yang berbeda-beda, namun secara umum bahasa pemrograman yang digunakan adalah bahasa tingkat rendah. Hambatan dalam penggunaan bahasa tingkat rendah diantaranya yaitu sulit dimengerti oleh bahasa manusia, sehingga dibuatlah sebuah compiler sebagai penerjemah menggunakan bahasa tingkat tinggi. 
Mikrokontroller keluaran Atmega mampu menggunakan bahasa tingkat tinggi yang banyak dikembangkan, diantaranya adalah bahasa Basic, bahasa $\mathrm{C}$, dan bahasa Pascal. Pada rancang bangun alat ini menggunakan bahasa $\mathrm{C}$ dengan menggunakan CodeVision AVR sebagai perangkat lunak pembuat project dan ISP Khazama sebagai program pengunduh.

\section{J. Perangkat Lunak CodeVision AVR}

CodeVision AVR adalah perangkat lunak pengkompiler menggunakan bahasa $\mathrm{C}$ berbasis Windows. Bahasa $\mathrm{C}$ merupakan salah satu bahasa yang cukup populer dan handal untuk pemograman mikrokontoler. CVAVR hanya dapat digunakan pada mikrokontroler keluarga AVR. Tampilan jendela awal dari CodeVision AVR pada gambar 6.

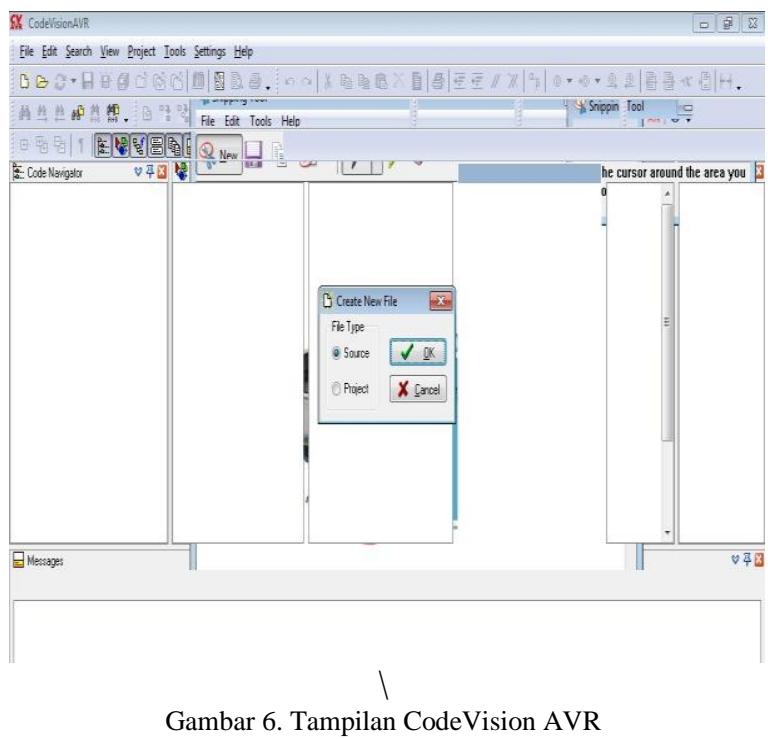

\section{K. ISP Downloader Khazama - AVR}

Perangkat lunak ISP khazama AVR programmer berfungsi sebagai kompilasi dan pengunduh program pada alat rangkaian yang akan dijalankan. Fitur - fitur yang dimiliki sangat memudahkan penggunanya, pengaturan yang praktis dan tidak rumit menjadi kelebihannya. Perangkat lunak pengunduh ini akan meng-unduh file berekstensi “.hex" ke mikrokontroler. Pada gambar 7. berikut adalah tampilan awal jendela perangkat lunak Khazama - AVR programmer.

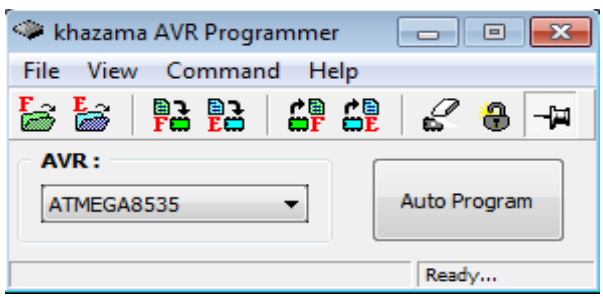

Gambar 7. Tampilan Jendela Khazama AVR Programmer

\section{PERANCANGAN SISTEM}

\section{A. Perancangan Perangkat Keras (Hardware)}

Perancangan dari perangkat keras (hardware) pada sistem parkir ini menggunakan beberapa macam interface yang terhubung secara langsung dengan mikrokontroler ATMega 8535 sebagai pusat pengolah data yang berkaitan dengan input atau output sistem. Gambar 8. menunjukkan diagram blok perancangan sistem masuk area parkir.

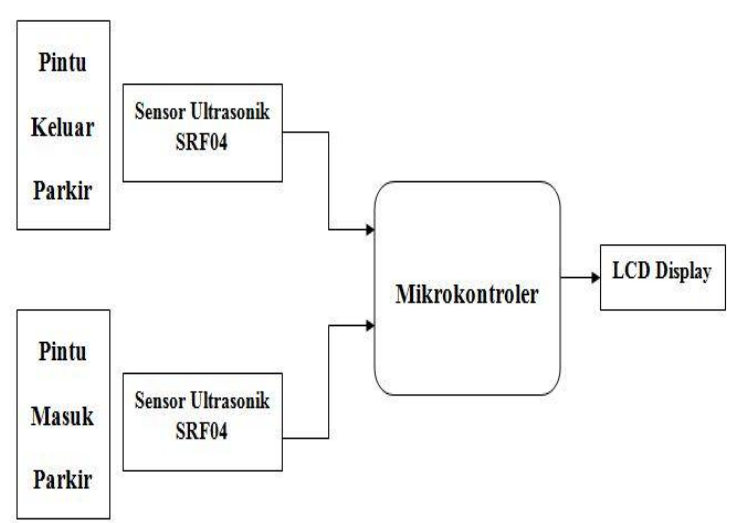

Gambar 8. Diagram Blok Sistem

\section{B. Perancangan Perangkat Lunak ( Software)}

Perancangan software ini, menggunakan bahasa $\mathrm{C}$ sebagai bahasa pemrograman dan CodeVisionAVR sebagai program kompilasi pada mikrokontroler ATMega 8535. Aplikasi ini digunakan untuk menuliskan program yang akan dibuat yang akan disimpan dalam ekstensi *.c. Kemudian dapat dikompilasi menjadi ekstensi *.hex. kemudian di-load dengan menggunakan program downloader Khazama AVR Programmer. Berikut diagram alir sistem yang ditunjukan oleh gambar 9.

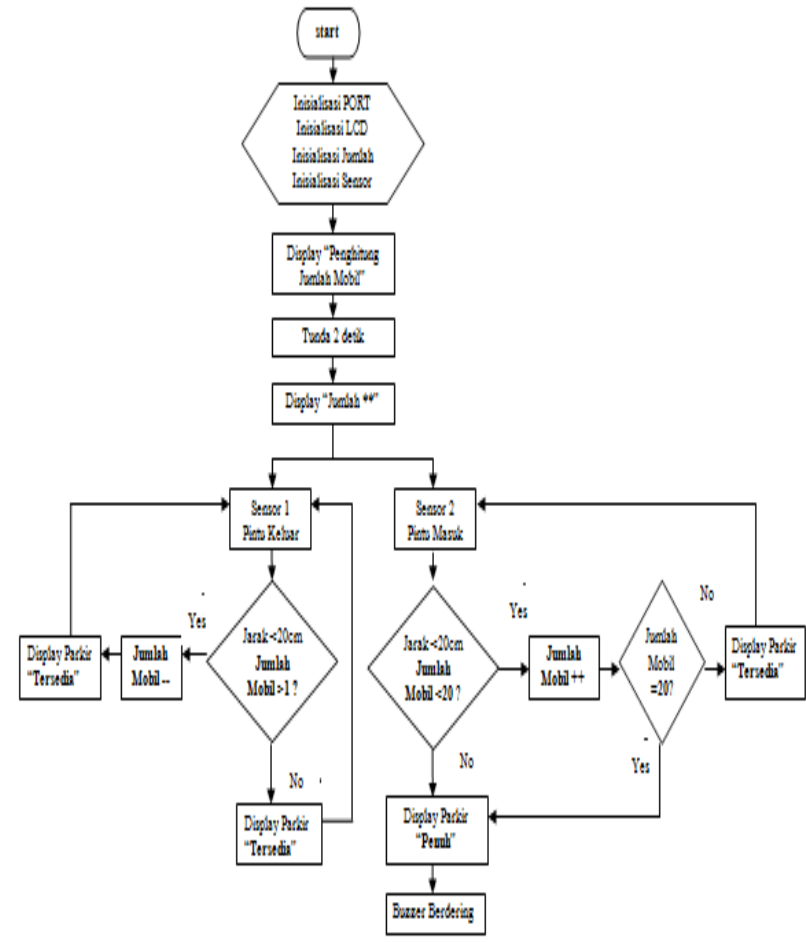

Gambar 9. Diagram Alir Sistem

Adapun tahapannya adalah menuliskan kode program, mengkompilasi, dan mengunduh program ke mikrokontroler ATMega 8535 yakni dengan menggunakan perangkat lunak CodeVisionAVR dan aplikasi pengunduh Khazama AVR Programmer.

\section{Desain Rangkaian}

Pembuatan rangkaian ini membutuhkan beberapa komponen yang paling utama yaitu sensor ultrasonik SRF04 terdiri dari pengirim (transmitter) dan penerima (receiver), mikrokontroler ATMega 8535, LCD untuk menampilkan jumlah kendaraan 
yang parkir dan buzzer sebagai indikator bunyi. Transmiter (TX) akaan mengirimkan sebuah sinyal jika mengenai penghalang kemudian sinyal pantulan akan diterima Receiver (RX) yang kemudian dikirimkan menuju mikrokontroler yang didalamnya sudah terdapat program untuk menghitung jumlah dan diperlihatkan hasilnya melalui LCD. Dan terakhir sebagai indikator suara, rangkaian ini telah dilengkapi dengan buzzer. Bunyi dari buzzer diatur sesuai jumlah kendaraan. Skematik rangkaian lengkap terlihat pada gambar 10 . berikut.

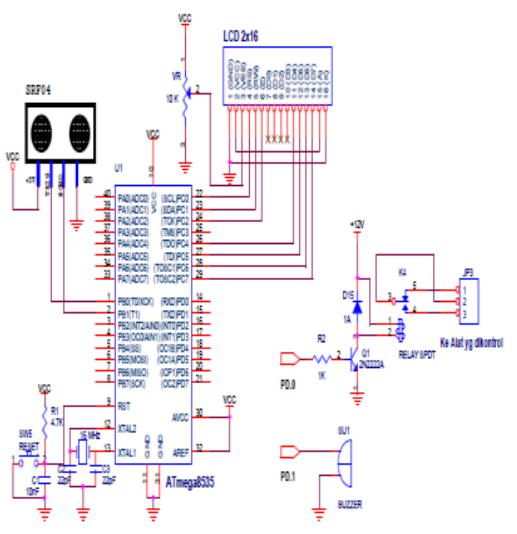

Gambar 10. Desain Rangkaian Sensor

\section{Tahap Penyelesaian}

Tahap dimana setelah selesai melakukan perancangan alatalat, langkah selanjutnya adalah perakitan. Tahap perakitan dimulai dengan urutan sebagai berikut :

a) Menggabungkan rangkaian - rangkaian yang telah dibuat seperti komponen elektronik, minimum sistem ATMega 8535, sensor ultrasonik SRF04, LCD dan buzzer dirangkai sesuai dengan perancangan yang telah dibuat. Komponen dipasang pada tempatnya sesuai dengan layout PCB yang tersedia. PCB yang sudah dipasangi komponen elektronik dan komponen mikrokontroler dipasang ke dalam box supaya memudahkan dalam penggunaannya.

b) Menuliskan program kemudian program tersebut diunduh ke mikrokontroler ATMega 8535. Pemrograman dilakukan setelah semua komponen elektronika dan komponen mikrokontroler terpasang dengan benar. Pemrograman dilakukan menggunakan bahasa Assembler. Listing program ditulis menggunakan program Notepad dan berkas disimpan dengan ekstensi “.asm”. Selanjutnya berkas ".asm" tersebut dimuat dengan program kompilasi CodeVisionAVR untuk diubah menjadi berkas ".hex". Setelah berkas tersebut diubah menjadi berkas ".hex" kemudian dimuat dengan menggunakan program Khazama AVR Programmer. Tujuannya adalah untuk memasukkan program mikro yang dibuat ke dalam sistem mikrokontroler ATMega 8535.

c) Melakukan uji coba terhadap alat yang telah berisi program secara keseluruhan dan untuk memastikan bahwa alat telah dapat bekerja sesuai dengan kebutuhan. Ujicoba dilakukan dengan melakukan tes menggunakan di lokasi yang didesain layaknya tempat parkir sebenarnya dan posisi yang divariasikan berdasarkan tingkat presisi dan keakuratan alat.

\section{IMPLEMENTASI DAN PENGUJIAN}

\section{A. Pengujian Rangkaian}

Tahap pembuatan alat penghitung kendaraan pada pintu masuk parkir mobil berbasis mikrokontroler Atmega 8535 selesai, dan tahap ini adalah proses pengujian dan pembahasan tentang kinerja dari alat ini.

Sistem yang terlihat pada gambar 11. terdiri dari perangkatperangkat meliputi sensor ultrasonik SRF04, sistem mikrokontroler dan LCD 16x2 downloader, buzzer, dan power supply $5 \mathrm{vdc}$

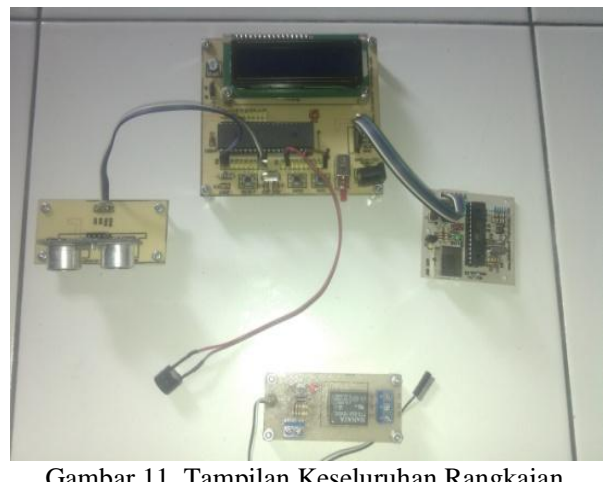

\section{B. Rencana Pengujian Rangkaian}

Pengujian rangkaian penghitung jumlah kendaraan ini dimulai dengan sistem peragaan kondisi parkir, dan memasang perangkat dengan penempatan yang telah ditentukan sebelumnya. Perangkat ditempatkan dipintu masuk dengan penempatan sensor pada pintu masuk dan keluar.

tahap pengujian dimulai dari pengujian keras (hardware), pengujian yang kedua adalah perangkat lunak (software) dengan menggunakan CodeVisionAVR sebagai pemrograman alat dan terakhir adalah pegujian secara keseluruhan.

\section{Pengujian Perangkat Keras}

a) Pengujian LCD $16 \times 2$

Pengujian LCD 16x2 dilakukan guna memprogram karakter atau tulisan yang ingin ditampilkan pada LCD. Berikut adalah contoh program untuk menginisialisasi LCD :

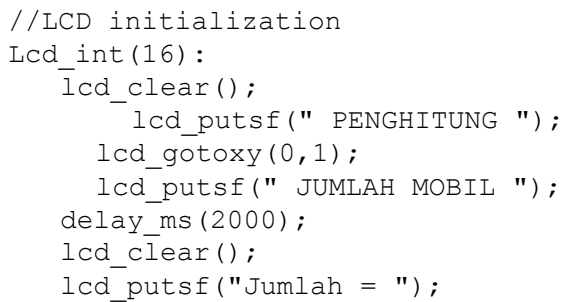

Seluruh kode program tersebut dikompilasi dan diunduh pada mikrokontroler, hasil yang muncul pada LCD terlihat pada gambar 12 .

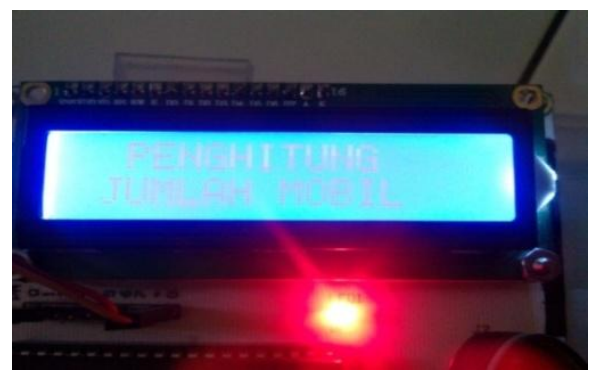

Gambar 12. Tampilan pada LCD 
b) Pengujian Perangkat Input

Sesuai pengujian perangkat input adalah memasangkan sensor ultrasonik SRF04 ke mikrokontroler. Untuk menghubungkan keduanya membutuhkan 4 pin. Satu pin disambung ke pin Trig dan satu lagi ke Echo. Ditambah dengan satu pin power supply : Vcc (sensor) terhubung ke Vec mikrokontroler demikian juga untuk gnd pada sensor dan mikrokontroler. Pada Tabel I, dibawah ini merupakan hubungan antara pin pada mikrokontroler dengan pin sensor ultrasonik SRF04.

TABEL I

HUBUNGAN ANTAR PIN

\begin{tabular}{|c|c|}
\hline Pin Mikrokontroler & Pin Sensor Ultrasonik SRF04 \\
\hline PORTB.0 & Trig \\
\hline PORTB. 1 & Echo \\
\hline Vcc & Vcc \\
\hline Gnd & Gnd \\
\hline
\end{tabular}

Hubungan antara LCD dan mikrokontroler. Dengan melihat skematik, maka didapatkan hubungannya seperti pada Tabel II.

TABEL II

HubunGAN ANTARA PIN MIKRO DAN LCD
\begin{tabular}{|c|c|}
\hline Pin Atmega 8535 & Pin LCD \\
\hline PORTC.0 & RS \\
\hline PORTC. 1 & RW \\
\hline PORTC. 2 & E \\
\hline PORTC. 4 & D 4 \\
\hline PORTC. 5 & D 5 \\
\hline PORTC. 6 & D 6 \\
\hline PORTC.7 & D 7 \\
\hline
\end{tabular}

Pengujian perangkat input sensor yang digunakan dalam rangkaian yang digunakan setelah melihat tabel skematik antara pin mikrokontroler dengan sensor ultrasonik SRF04 dapat menggunakan rangkaian seperti pada gambar 13 .

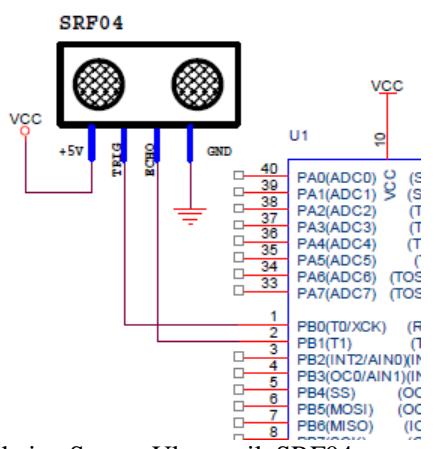

Gambar 13. Rangkaian Sensor Ultrasonik SRF04

Percobaan tentang pengaruh dari objek bergerak untuk menguji kinerja dari sensor. Percobaan ini dilakukan dengan kondisi pengukuran yang dilakukan adalah membuat jarak pengukuran objek pada jarak $50 \mathrm{~cm}$ dan 100 cm. Dan objek yang digunakan sepęa motor dan mobil merupakan kendaraan bermotor dan terakhir adalah manusia. Dengan cara objek bergerak tepat di depan sensor seperti pada gambar 14 .

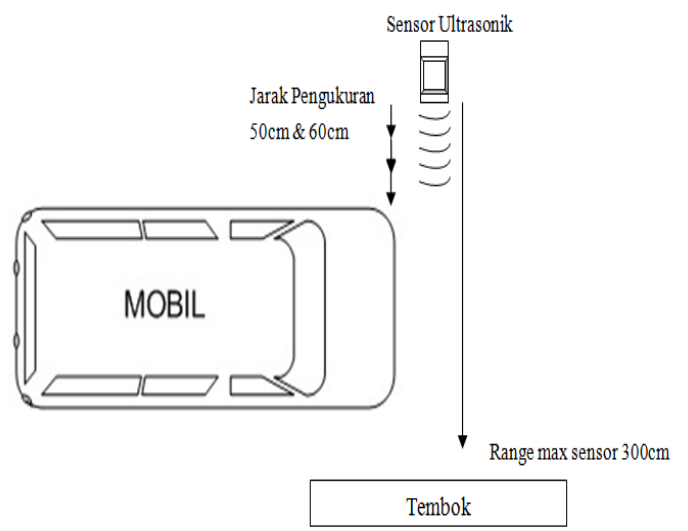

Gambar 14. Percobaan Pengaruh Objek Bergerak Pada Sensor

Dengan cara memberikan objek bergerak yang melintas di depan sensor ultrasonik SRF04 dengan kecepatan antara $10 \mathrm{~km} / \mathrm{jam}$ dan $50 \mathrm{~km} / \mathrm{jam}$ sedangkan rentang jarak dari objek antara $50 \mathrm{~cm}$ sampai $100 \mathrm{~cm}$. Untuk menyatakan kondisi kolom status dinyatakan dengan "Terdeteksi" dan jika buzzer berbunyi atau ada perubahan jumlah yang tertera di LCD. Berikut Tabel III hasil evaluasi terhadap objek bergerak contohnya kendaraan bermotor.

TABEL III

HASIL EVALUASI TERHADAP OBJEK BERGERAK

\begin{tabular}{|c|c|c|c|}
\hline Percobaan & $\begin{array}{c}\text { Kecepatan } \\
(\mathrm{Km} / \mathrm{jam})\end{array}$ & Jarak $(\mathrm{Cm})$ & Status \\
\hline 1 & 10 & 50 & Terdeteksi \\
\hline 2 & 20 & 50 & Terdeteksi \\
\hline 3 & 30 & 50 & Terdeteksi \\
\hline 4 & 40 & 50 & Tidak Terdeteksi \\
\hline 5 & 50 & 50 & Tidak Terdeteksi \\
\hline 6 & 10 & 100 & Terdeteksi \\
\hline 7 & 20 & 100 & Terdeteksi \\
\hline 8 & 30 & 100 & Terdeteksi \\
\hline 9 & 40 & 100 & Tidak Terdeteksi \\
\hline 10 & 50 & 100 & Tidak Terdeteksi \\
\hline
\end{tabular}

Percobaan yang telah dilakukan dengan kecepatan dan jarak yang berbeda-beda. Interval kecepatan yang digunakan saat percobaan sebesar $50 \mathrm{~km} / \mathrm{jam}$ dan 100 $\mathrm{km} / \mathrm{jam}$ dengan rentang jarak $50 \mathrm{~cm}$ dan $100 \mathrm{~cm}$. Pada kecepatan tertentu ada keadaan dimana sensor "tidak mendeteksi" objek, dikarenakan kecepatan (cepat rambat) gelombang ultrasonik di udara $=344 \mathrm{~m} / \mathrm{s}$ (meter perdetik). Artinya untuk menempuh jarak 344 m dibutuhkan waktu 1 detik. Atau untuk menempuh jarak $1 \mathrm{~m}$ butuh waktu 1/344 s atau 0,0029 s. Gelombang ultrasonik melakukan perjalanan pergi-pulang (pancar-terima) sehingga waktu yang dibutuhkan menjadi 2x. Hal ini berpengaruh pada perhitungan jaraknya. Waktu tempuh menjadi 2x, sehingga untuk menempuh jarak $1 \mathrm{~cm}$ diperlukan waktu $29 \mu \mathrm{s}$ × $2=58 \mu \mathrm{s}$. Sehingga dapat 
disimpulkan dari percobaan yang telah dilakukan kecepatan mempengaruhi kemampuan sensor, maka dari itu pada percobaan terakhir kecepatan dari objek dibatasi kurang dari $40 \mathrm{~km} / \mathrm{jam}$.

c) Pengujian Perangkat Output

perangkat output adalah pengujian buzzer yang digunakan dalam sistem pengitung jumlah kendaraan secara otomatis. Tujuan dari pengujian adalah untuk mengetahui apakah perangkat output seperti buzzer dapat bekerja dengan baik dan dapat dikendalikan oleh sistem kontrol.

d) Pemrograman Alat

pemrograman alat dilakukan setelah rangkaian perangkat keras selesai dibuat. Seluruh perangkat keras tersebut diuji apakah sudah sesuai dan tidak terjadi kesalahan dalam perangkainnya. Kemudian program dimasukkan kedalam mikrokontroler Atmega 8535 sehingga alat dapat menampilkan hasilnya, maka alat tersebut dalam keadaan baik. Untuk membuat project program mikrokontroler Atmega 8535 menggunakan perangkat lunak CodeVisionAVR.

Apabila kode program selesai dibuat dan dikompilasi dengan masuk ke program ISP Khazama - AVR. ISP Khazama - AVR adalah sebuah perangkat lunak yang digunakan untuk meng-unduh berkas .hex ke mikrokontroler, prosesnya dengan menghubungkan ke komputer atau laptop melalui port USB menggunakan perangkat pengunduh. program ISP Khazama AVR seperti gambar 15. di bawah ini.

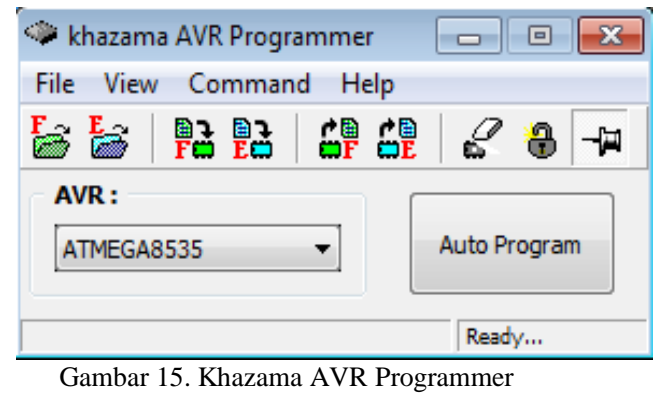

\section{e) Pengujian Rangkaian Keseluruhan}

Pengujian rangkaian keseluruhan dilakukan setelah pengecekan mulai dari bagian masing-masing rangkaian penyusun dan pengisian program ke dalam IC mikrokontroler Atmega 8535. Dari sisi pengujian yang dilakukan baik hardware maupun software terhadap kinerja masing-masing komponen untuk mendapatkan hasil yang maksimal dan sesuai harapan. Pengujian secara keseluruhan pada perangkat dilakukan pada area parkir sebagai tujuan utama dari pembuatan alat ini dengan mengatur objek melintas di depan sensor.

Pengujian sebelumnya dengan kondisi pengukuran yang dilakukan adalah jarak pengukuran antara sensor dengan objek (range) pada jarak minimal $20 \mathrm{~cm}$ dan jarak maksimal sampai dengan $100 \mathrm{~cm}$. Apabila ada objek yang memotong jarak antara sensor dengan tembok atau penghalang yang ditentukan, maka disimpulkan ada objek melintas dan jumlah akan terus bertambah dengan sensor dipintu masuk dan jumlah akan berkurang dengan sensor pada pintu keluar. Desain tempat parkir yang digunakan saat pengujian ada pada gambar 16 .

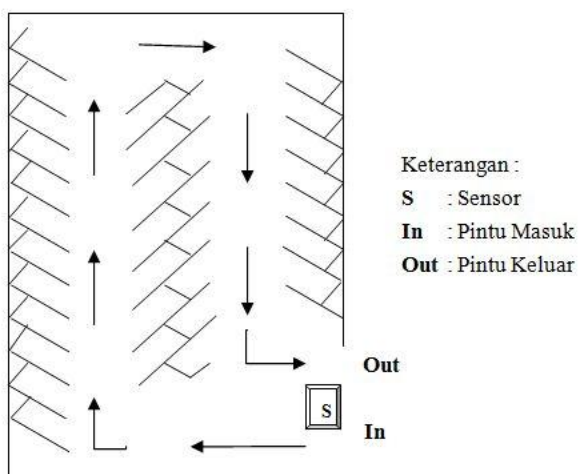

Gambar 16. Desain Tempat Parkir Pengujian

Desain pada gambar 4.6 tersebut dengan kondisi objek akan melintasi sensor saat masuk tempat parkir dan keluar tempat parkir. Objek yang digunakan adalah kendaraan bermotor khususnya mobil yang bergerak tepat di depan sensor. Dengan asumsi panjang rata-rata mobil yang beredar di indonesia adalah 4 meter, serta lebar kurang lebih 1,5 meter. Pembatasan kecepatan penting dilakukan mengingat pada percobaan saat pengujian sebelumnya kendaraan melintas di depan sensor ultrasonik SRF04 tidak lebih dari 40 km/jam, jika kecepatan lebih tinggi maka keakuratan sensor menjadi terganggu. Penempatan perangkat dan sensor yang di-ilustrasikan pada gambar 17. berikut.

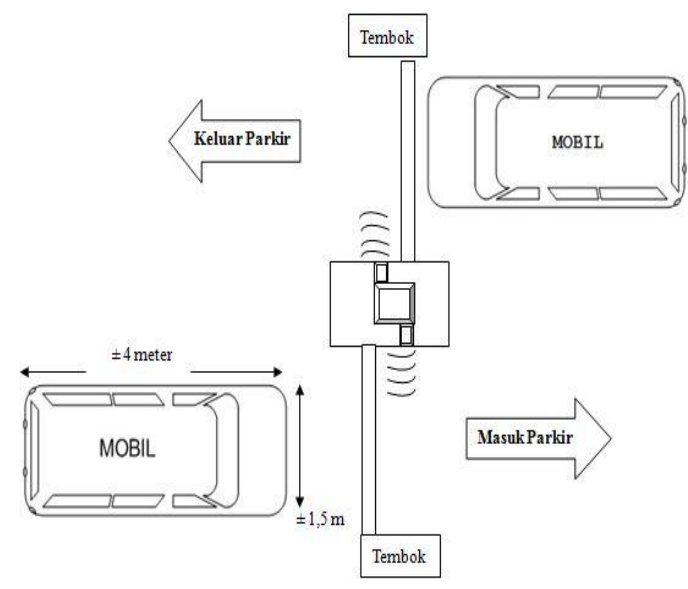

Gambar 17. Desain Penempatan Perangkat dan Sensor

Kondisi saat pengujian akhir adalah satu arah untuk masuk parkir dan keluar parkir dan tidak bolak-balik. Untuk menandakan kendaraan yang melintas, maka buzzer berbunyi "rendah" dan dengan otomatis terjadi perubahan jumlah serta kondisi akan tertera di LCD dan apabila berbunyi "tinggi" dan lama berarti parkir telah "penuh". Tampilan pada LCD ditunjukan seperti pada gambar 18 . berikut.

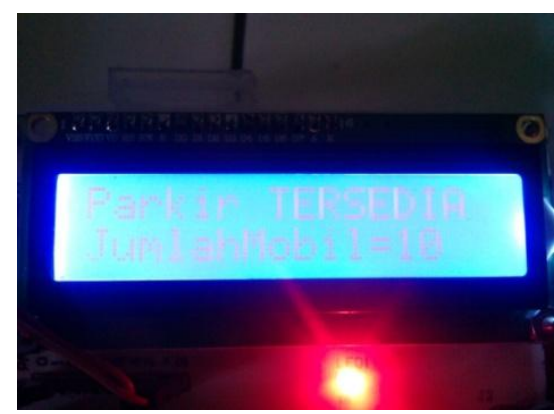

Gambar 18. Tampiln Pada LCD 
Hasil dari pengujian keseluruhan perangkat seperti yang tertera pada tabel IV hasil percobaan pada mobil :

TABEL IV

HAsil PENGUJian AKHIR PADA MoBIL Di PINTU PARKIR

\begin{tabular}{|c|c|c|c|c|c|}
\hline Percobaan & $\begin{array}{c}\text { Jarak } \\
(\mathrm{cm})\end{array}$ & $\begin{array}{c}\text { Jumlah } \\
\text { Mobil }\end{array}$ & $\begin{array}{l}\text { Bunyi } \\
\text { Buzzer }\end{array}$ & $\begin{array}{l}\text { Status } \\
\text { Parkir }\end{array}$ & $\begin{array}{l}\text { Status } \\
\text { Mobil }\end{array}$ \\
\hline 1 & 30 & 1 & Rendah & Tersedia & Masuk \\
\hline 2 & 30 & 2 & Rendah & Tersedia & Masuk \\
\hline 3 & 30 & 3 & Rendah & Tersedia & Masuk \\
\hline 4 & 30 & 4 & Rendah & Tersedia & Masuk \\
\hline 5 & 30 & 5 & Rendah & Tersedia & Masuk \\
\hline 6 & 30 & 6 & Rendah & Tersedia & Masuk \\
\hline 7 & 30 & 7 & Rendah & Tersedia & Masuk \\
\hline 8 & 30 & 8 & Rendah & Tersedia & Masuk \\
\hline 9 & 30 & 9 & Rendah & Tersedia & Masuk \\
\hline 10 & 30 & 10 & Rendah & Tersedia & Masuk \\
\hline 11 & 30 & 11 & Rendah & Tersedia & Masuk \\
\hline 12 & 30 & 12 & Rendah & Tersedia & Masuk \\
\hline 13 & 30 & 13 & Rendah & Tersedia & Masuk \\
\hline 14 & 30 & 14 & Rendah & Tersedia & Masuk \\
\hline 15 & 30 & 15 & Rendah & Tersedia & Masuk \\
\hline 16 & 30 & 16 & Rendah & Tersedia & Masuk \\
\hline 17 & 30 & 17 & Rendah & Tersedia & Masuk \\
\hline 18 & 30 & 18 & Rendah & Tersedia & Masuk \\
\hline 19 & 30 & 19 & Rendah & Tersedia & Masuk \\
\hline 20 & 30 & 20 & Tinggi & Penuh & Masuk \\
\hline 21 & 30 & 20 & Tinggi & Penuh & Masuk \\
\hline 22 & 30 & 20 & Tinggi & Penuh & Masuk \\
\hline 23 & 30 & 19 & Rendah & Tersedia & Keluar \\
\hline 24 & 30 & 18 & Rendah & Tersedia & Keluar \\
\hline 25 & 30 & 17 & Rendah & Tersedia & Keluar \\
\hline
\end{tabular}

Data hasil pengujian akhir didapat dengan mengatur jarak sensor dengan objek pada jarak $20 \mathrm{~cm}$ hingga jarak $100 \mathrm{~cm}$ baik saat ada kendaraan masuk dan keluar tempat parkir. Dengan menggunakan kondisi kecepatan mobil yang telah ditetapkan sebelumnya yakni kurang dari 40 km/jam. Kolom status parkir menjadi "Penuh" dikarenakan pengaturan jumlah maksimal yang telah diatur pada kode program adalah jika jumlah mobil sama dengan 20. Dan jika kurang dari 20 tampilan status parkir menjadi "Tersedia". Pada kolom status mobil "Masuk" berarti ada mobil yang masuk area parkir dan status "Keluar" berarti mobil telah meninggalkan area parkir. Dalam pengujian akhir ini menggunakan tanda bunyi dari Buzzer untuk membedakan ketika jumlah mobil 1 - 19 bunyi rendah dengan jeda, dan jika jumlah mobil 20 bunyi buzzer lama dan "Tinggi" karena kondisi telah penuh.

Hasil pengujian dapat membuktikan bahwa sensor ultrasonik bekerja berdasarkan kemampuan objek memantulkan kembali gelombang ultrasonik yang dikirim oleh sensor ultrasonik, gangguan pada pendeteksiaan sensor ultrasonik dapat diakibatkan oleh karakteristik objek yang kurang mampu untuk memantulkan gelombang suara dengan baik.

Jurnal Teknologi dan Sistem Komputer, Vol.3, No.2, April 2015 (e-ISSN: 2338-0403)

\section{A. Kesimpulan}

\section{KESIMPULAN DAN SARAN}

Berdasarkan hasil pengujian dan analisis alat penghitung otomatis, maka dapat diambil kesimpulan sebagai berikut :

1) Mikrokontroler ATMega 8535 berfungsi sebagai pengendali utama pada pemrosesan data jumlah mobil saat parkir yang dihasilkan dari sensor ultrasonik.

2) Sensor ultrasonik yang bekerja berdasarkan prinsip pantulan gelombang suara, dimana sensor akan menghasilkan gelombang suara yang kemudian menangkapnya kembali dengan perbedaan waktu sebagai dasar penginderaannya.

3) Gangguan pada pendeteksiaan sensor ultrasonik dapat diakibatkan oleh karakteristik penghalang yang kurang mampu untuk memantulkan gelombang suara dengan baik.

4) Sensor ultrasonik SRF04 dapat bekerja dengan baik sesuai dengan spesifikasi dari sensor ultrasonik SRF04 yaitu dapat memindai objek mulai dari jarak minimum 3 cm sampai dengan jarak maksimum 3 meter.

\section{B. Saran}

Terdapat beberapa saran dari hasil penelitian yaitu sebagai berikut :

1) Pengembangan Penghitung Jumlah Mobil Berbasis Mikrokontroler Atmega 8535. Dimana alat yang dibuat tidak hanya dalam bentuk prototipe, tetapi diuji pada keadaan sesungguhnya

2) Penggunaan reset untuk mempermudah saat mengembalikan ke kondisi awal.

3) Memperkecil arah dan jangkauan sensor ultrasonik

4) Kecepatan objek dibatasi sehingga memudahkan dalam pengujian

\section{DAFTAR PUSTAKA}

[1] Sudjadi. (2005). Teori dan Aplikasi Mikrokontroler.Yogyakarta: Graha Ilmu.

[2] Kristanto, Andri. (2003). Bahasa Assembler. Yogyakarta: Gaya Media.

[3] Bejo, Agus. (2008). C \& AVR Rahasia Kemudahan Bahasa C Dalam Mikrokontroler ATMega 8535. Yogyakarta : Graha Ilmu.

[4] Wardhana, Lingga. (2006). Belajar Sendiri Mikrokontroler AVR Seri ATMega8535 Simulasi, Hardware, dan Aplikasi. Yogyakarta: Andi Offset.

[5] Heryanto, Ary dan Wisnu, Adi. (2008). Pemrograman Bahasa C untuk Mikrokontroler ATMEGA8535. Yogyakarta: Andi Offset.

[6] Prihono, (2009). Jago Elektronika Secara Otodidak, Jakarta : Kawan Pustaka.

[7] Putra, Agfianto Eko, (2005). Belajar Mikrokontroler AT89C51/52/53 (Teori dan Aplikasi), Yogyakarta : Gava Media.

[8] Yusuf, Muhamad. (2009). Prototipe Sensor Parkir Mobil Berbasis Mikrokontroler AT89S51. Surakarta. Universitas Sebelas Maret.

[9] Abadi, Delta Agus Setya. (2008). Sensor Ultrasonik Sebagai Alat Navigasi Robot Pada Robot Pemadam Api Berbasis Mikrokontroler ATMega 8535. Semarang. Teknik Elektro Universitas Diponegoro.

[10] Haryanto. (2005). Pemrogaman Bahasa C Untuk Mikrokontroler ATMega 8535. Jakarta : PT. Elex Media Komputindo.

[11] Tim lab. Mikroprosesor. (2006). Pemrograman Mikrokontroler AT89S51 dengan $\mathrm{C} / \mathrm{C}++$. Yogyakarta: Andi.

[12] Maryanto, Hendra. (2010). Pembuatan Prototipe Pintu Otomatis Satu Arah Berbasis Mikrokontroler ATMega 8535 Menggunakan Double IR. Surakarta. Ilmu Komputer Fakultas Matematika Dan Ilmu Pengetahuan Alam Universitas Sebelas Maret.

[13] Andrianto, Heri. (2008). Pemrograman Mikrokontroler AVR ATMEGA 16 Menggunakan Bahasa C (CodeVisionAVR). Bandung : INFORMATIKA.

[14] Ebiezer. (2010). Perancangan Pembuka Pintu menggunakan sensor PIR. Penulisan Ilmiah. Jakarta. Universitas Gunadarma. 